\title{
Determinants of Grape Growers about Adoption of Safety Measures in Pesticide Application
}

\author{
S. N. Gayakwad*, N. D. Deshmukh, D. D. Suradkar and S. R. Gaikwad \\ Department of Extension Education, college of Agriculture, Latur, India \\ *Corresponding author
}

\begin{tabular}{|l|}
\hline Ke y w o r d s \\
$\begin{array}{l}\text { Profile, Grape } \\
\text { growers, Adoption, } \\
\text { Safety measures }\end{array}$ \\
\hline Article Info \\
\hline $\begin{array}{l}\text { Accepted: } \\
\text { 12 November } 2020 \\
\text { Available Online: } \\
\text { 10 December } 2020\end{array}$ \\
\hline
\end{tabular}

A B S T R A C T

\begin{abstract}
The present study was conducted in purposively selected Jalna district of Marathwada region of Maharashtra state as it is having highest area under grapes cultivation. From the district, four major grape growing villages identified and from each village 30 grape growers were selected which constitute 120 respondents. Ex-post facto research design was used for the investigation. The results of profile of the grape growers revealed that, majority of the grape growers were middle aged $(68.33 \%)$, had secondary level educated $(41.67 \%)$, were medium experience of grape cultivation (71.67\%), had semi- medium land holding (43.33\%), had medium area under grape (89.17\%), medium annual income $(75.83 \%)$, most of them had low level of social participation $(52.50 \%)$, using medium sources of information $(68.33 \%$ ), most of them had medium level of economic motivation $(85.00 \%)$, had medium level of knowledge $(82.50 \%)$, most of them had medium level of risk orientation $(74.17 \%)$ and innovativeness $(58.34 \%)$. As regards to the relational analysis it is observed that, independent variables like education and knowledge of grape growers established positive and highly significant association with adoption of safety measures in pesticide application and experience in grape cultivation, annual income, sources of information, economic motivation, risk orientation and innovativeness of the grape growers had found to be positive and significant with their adoption. While land holding, area under grape and social participation of grape growers had found nonsignificant relationship with adoption and age was negatively significant with adoption.
\end{abstract}

\section{Introduction}

Grape is an important commercial fruit crop of India which contributes to the maximum share of export of fresh fruits and vegetables from India to Europe and other parts of the world. Maharashtra is the largest grape producing state in the country with an area of 105.50 thousand hectares under grapes cultivation and annual production is around 2286.44 thousand tons.
Farmers are using excessive amount of pesticides in a wrong manner with disproportionate dosage, which leads lo high cost of cultivation as well as ecological imbalance.

The economic loss is enormous since these highly poisonous chemical their way into the air and water system, including rain, fog and snow affecting often totally flora and fauna, even humans. Some of the chronic effects of 
pesticide on human being identified by the doctors are cancer, generic mutation and damage to the immune systems, kidneys and liver.

Hence, reducing the hazardous arise due to pesticides need immediate action to be taken by environmentalists and all other concern to mitigate the health hazardous to the enormous human population. In the society like India where farming is a family affair, the problem of reaching the target group gets further compounded.

The farming family as a whole needs to be educated, then only the damages could be checked or at least minimized to a safe level. Only when they start to understand the risks involved in the use of pesticides, then only changes can take place in the desired direction i.e. integrated pest management (IPM).

In the present study, efforts were taken to know the profile of grape growers and to delineate the relationship between profile of grape growers and adoption of safety measures in pesticide application by them.

\section{Materials and Methods}

The present study was conducted in purposively selected Jalna district of Marathwada region of Maharashtra state as it is having highest area under grapes cultivation. From Jalna district, four major grape growing villages i.e., Kadvanchi, Dharkalyan, Nandapur and Warud were selected purposively. From each village 30 grape growers were selected randomly which constitute sample of 120 respondents.

For the present investigation ex-post facto research design was used and statistical tools like mean, frequency, percentage, standard deviation and correlation co-efficient were applied for data analysis.

\section{Results and Discussion}

\section{Profile of the grape growers}

Age

The data presented in table 1 shows that majority of the grape growers $(68.33 \%)$ belonged to middle age group whereas, 20.00 per cent belonged to young and 11.67 per cent had old age group, respectively.

\section{Education}

It is observed that most of the grape growers $(41.67 \%)$ belonged to secondary education, while one-fourth $(25.00 \%)$ had higher secondary education, 24.16 per cent were primary educated, 07.50 per cent had graduated and only 01.67 per cent grape growers were illiterate.

\section{Experience in grape cultivation}

Table 1 also indicates that, majority of the grape growers $(71.67 \%)$ had medium experience in grape cultivation while, 15.83 per cent were low and 12.50 per cent had high experience of grape cultivation.

\section{Land holding}

The data pertaining to land holding reported that, most of the of grape growers $(43.33 \%)$ had semi-medium land holding, while that, 25.84 per cent had small followed by medium $(23.33 \%)$ land holding category. Only few grape growers were belonged to marginal $(05.83 \%)$ and big land holding category $(01.67 \%)$.

\section{Area under grape}

The data presented in Table 1 regarding area under grape cultivation depicts that, majority of the grape growers $(89.17 \%)$ were having medium area under grape, followed by high 
$(10.00 \%)$ and low $(00.83 \%)$ area under grape cultivation, respectively.

\section{Annual income}

The annual income data presented in Table 1 revealed that, majority of the grape growers $(75.83 \%)$ were having medium annual income while, 15.00 per cent had high and 09.17 per cent had low annual income, respectively.

\section{Social participation}

The data presented in Table 1 in respect of social participation depicted that, more than half of grape growers $(52.50 \%)$ were having low social participation whereas, 30.00 per cent had medium and 17.50 per cent had high social participation.

Table.1 Distribution of grape growers according to their profile $n=120$

\begin{tabular}{|c|c|c|c|c|}
\hline $\begin{array}{l}\text { Sr. } \\
\text { No. }\end{array}$ & Variables & Category & Frequency & Percentage \\
\hline \multirow[t]{4}{*}{1.} & \multirow[t]{4}{*}{ Age } & Young (up to 25) & 24 & 20.00 \\
\hline & & Middle (26-41) & 82 & 68.33 \\
\hline & & Old (above 41) & 14 & 11.67 \\
\hline & & Total & 120 & 100 \\
\hline \multirow[t]{6}{*}{2.} & \multirow[t]{5}{*}{ Education } & Illiterate & 02 & 01.67 \\
\hline & & Primary education $\left(\mathrm{Std} 1^{\text {st }}\right.$ to $\left.7^{\text {th }}\right)$ & 29 & 24.16 \\
\hline & & Secondary education $\left(\operatorname{Std} 8^{\text {th }}\right.$ to $\left.10^{\text {th }}\right)$ & 50 & 41.67 \\
\hline & & Higher secondary education $\left(11^{\text {th }}\right.$ to $\left.12^{\text {th }}\right)$ & 30 & 25.00 \\
\hline & & Graduated & 09 & 07.50 \\
\hline & & Total & 120 & 100 \\
\hline \multirow[t]{4}{*}{3.} & \multirow{3}{*}{$\begin{array}{l}\text { Experience of } \\
\text { grape cultivation }\end{array}$} & Low (up to 2 years) & 19 & 15.83 \\
\hline & & Medium (3-9 years) & 86 & 71.67 \\
\hline & & High (above 9 years) & 15 & 12.50 \\
\hline & & Total & 120 & 100 \\
\hline \multirow[t]{5}{*}{4.} & \multirow[t]{5}{*}{ Land holding } & Marginal (up to 1.00 ha.) & 7 & 05.83 \\
\hline & & Small (1.0 to 2.00 ha.) & 31 & 25.84 \\
\hline & & Semi medium (2.01 to 4.00 hq.) & 52 & 43.33 \\
\hline & & Medium (4.01 to 10.00 hq.) & 28 & 23.33 \\
\hline & & Total & 120 & 100 \\
\hline \multirow[t]{4}{*}{5.} & \multirow{4}{*}{$\begin{array}{l}\text { Area under grape } \\
\text { cultivation }\end{array}$} & Low (up to 0.30 hq.) & 01 & 0.83 \\
\hline & & Medium (0.31 to 2.00 hq.) & 107 & 89.17 \\
\hline & & High (above 2.00 hq.) & 12 & 10.00 \\
\hline & & Total & 120 & 100 \\
\hline \multirow[t]{4}{*}{6.} & \multirow[t]{4}{*}{ Annual income } & Low (up to Rs. $6,99,298$ ) & 11 & 09.17 \\
\hline & & Medium (Rs. 6,99,299 to Rs. 23,81,701) & 91 & 75.83 \\
\hline & & High (above Rs. 23,81,701) & 18 & 15.00 \\
\hline & & Total & 120 & 100 \\
\hline \multirow[t]{2}{*}{7.} & \multirow{2}{*}{$\begin{array}{l}\text { Social } \\
\text { participation }\end{array}$} & Low (up to 3) & 63 & 52.50 \\
\hline & & Medium (4 to 5 ) & 36 & 30.00 \\
\hline
\end{tabular}




\begin{tabular}{|c|c|c|c|c|}
\hline & & High (above 5) & 21 & 17.50 \\
\hline & & Total & 120 & 100 \\
\hline \multirow[t]{4}{*}{8.} & \multirow{4}{*}{$\begin{array}{l}\text { Sources of } \\
\text { information }\end{array}$} & Low (up to 46) & 24 & 20.00 \\
\hline & & Medium (47 to 53) & 82 & 68.33 \\
\hline & & High (above 53) & 14 & 11.67 \\
\hline & & Total & 120 & 100 \\
\hline \multirow[t]{4}{*}{9.} & \multirow{3}{*}{$\begin{array}{l}\text { Economic } \\
\text { motivation }\end{array}$} & Low (up to 24) & 10 & 08.33 \\
\hline & & Medium (25 to 28 ) & 102 & 85.00 \\
\hline & & High (above 28) & 08 & 06.67 \\
\hline & & Total & 120 & 100 \\
\hline \multirow[t]{4}{*}{10.} & \multirow[t]{3}{*}{ Knowledge } & Low (up to 33 ) & 10 & 08.33 \\
\hline & & Medium (34 to 38) & 99 & 82.50 \\
\hline & & High (above 38) & 11 & 09.17 \\
\hline & & Total & 120 & 100 \\
\hline \multirow[t]{4}{*}{11 . } & \multirow[t]{3}{*}{ Risk orientation } & Low (up to 21) & 24 & 20.00 \\
\hline & & Medium (22 to 25) & 89 & 74.17 \\
\hline & & High (above 25) & 07 & 05.83 \\
\hline & & Total & 120 & 100 \\
\hline \multirow[t]{4}{*}{12.} & \multirow{3}{*}{ Innovativeness } & Low (up to 19) & 34 & 28.33 \\
\hline & & Medium (20 to 22) & 70 & 58.34 \\
\hline & & High (above 22) & 16 & 13.33 \\
\hline & & Total & 120 & 100 \\
\hline
\end{tabular}

Table.2 Relationship between profile of grape growers and adoption of safety measures in pesticide application by them

\begin{tabular}{|c|l|c|}
\hline Sr. No. & Independent variables & Co-efficient of correlation \\
\hline $\mathbf{1 .}$ & Age & $-0.196^{*}$ \\
\hline $\mathbf{2 .}$ & Education & $0.444^{* *}$ \\
\hline $\mathbf{3 .}$ & Experience in grape cultivation & $0.195^{*}$ \\
\hline $\mathbf{4 .}$ & Land holding & $0.0189^{\mathrm{NS}}$ \\
\hline $\mathbf{5 .}$ & Area under grape & $0.0813^{\mathrm{NS}}$ \\
\hline $\mathbf{6 .}$ & Annual income & $0.194^{*}$ \\
\hline $\mathbf{7 .}$ & Social participation & $0.0294^{\mathrm{NS}}$ \\
\hline $\mathbf{8 .}$ & Sources of information & $0.199^{*}$ \\
\hline $\mathbf{9 .}$ & Economic motivation & $0.206^{*}$ \\
\hline $\mathbf{1 0 .}$ & Knowledge & $0.906^{* *}$ \\
\hline $\mathbf{1 1}$ & Risk orientation & $0.201^{*}$ \\
\hline $\mathbf{1 2}$ & Innovativeness & $0.197^{*}$ \\
\hline
\end{tabular}

* Significant at 0.05 level of probability

** Significant at 0.01 level of probability

${ }^{\text {NS }}$ Non-significant 


\section{Sources of information}

The data about use of sources of information by grape growers presented in Table 1 shows that, majority of the grape growers $(68.33 \%)$ were using medium sources of information, followed by 20.00 per cent had low and 11.67 per cent had high use of sources of information, respectively.

\section{Economic motivation}

Table 1 reveled that, majority of the grape growers $(85.00 \%)$ had medium level of economic motivation while that, only 08.33 per cent had low and 06.67 per cent had high level economic motivation.

\section{Knowledge}

It is observed from Table 1 that, majority of the grape growers $(82.50 \%)$ had medium knowledge about safety measures in pesticide application followed by high $(09.17 \%)$ and low (08.33\%) knowledge about safety measures in pesticide application, respectively.

\section{Risk orientation}

The data presented in Table 1 shows that, majority of the grape growers $(74.17 \%)$ were having medium risk orientation while, 20.00 per cent had low and 05.83 per cent had high risk orientation, respectively.

\section{Innovativeness}

Table 1 depicted that, more than half of the grape growers $(58.34 \%)$ had medium innovativeness whereas, 28.33 per cent of them had low and 13.33 per cent had high innovativeness. Above findings are in line with the findings of Atar, 2012 and Deshmukh, 2013.

\section{Relationship between profile of grape growers and adoption of safety measures in pesticide application by them}

Table 2 shows that, variables like experience in grape cultivation, annual income, sources of information, economic motivation, risk orientation and innovativeness of the grape growers had found to be positive and significant relationship with the adoption of safety measures in pesticide application by the grape growers. While education and knowledge of grape growers had found positive and highly significant with their adoption of safety measures in pesticide application.

Whereas variables like land holding, area under grape and social participation had established non-significant relationship with adoption of safety measures in pesticide application by grape growers. The age of grape growers was negatively significant with their adoption of safety measures in pesticide application.

From the findings of study, it can be highlighted that in case of profile of the grape growers most of them belonged to medium category and significant relationship with the adoption except land holding, area under grapes and social participation and age was negatively significant with adoption of safety measures in pesticide applications.

\section{References}

Anonymous, 2018. Horticultural Statistics at a Glance 2018. (http://agricoop.nic.in)

Atar R. S., 2012. Study on knowledge and adoption of recommended grape cultivation practices by the grape growers, M.Sc. (Agri.), Thesis VNMKV, Parbhani.

Deshmukh B. A., 2013. Knowledge and adoption of plant protection measures 
by pomegranate growers in western Maharashtra, Ph.D. (Agri.) Thesis, MPKV, Rahuri.

Kumar R., A. Ahmad, R. K. Dular and D. Chahal, 2015. Knowledge and adoption of improved grape cultivation practices in Haryana, India. Agriculture Science
Digest.35 (1): 31-35.

Shikhamany S. D., 2001. 5. Grape production in India (http://www.fao.org).

Subash, S. P. 2018. Pesticide Use in Indian Agriculture. Trends, Market Structure and Policy Issues.

\section{How to cite this article:}

Gayakwad, S. N., N. D. Deshmukh, D. D. Suradkar and Gaikwad, S. R. 2020. Determinants of Grape Growers about Adoption of Safety Measures in Pesticide Application. Int.J.Curr.Microbiol.App.Sci. 9(12): 1588-1593. doi: https://doi.org/10.20546/ijcmas.2020.912.188 